\title{
ANalisis KesalahaN penulisan gairaigo pada maHasiswa tKol s.d IV pemokusan pada gairaigo bahasa inggris
}

\author{
Septian Eka Pratama, Herniwati', Renariah² \\ Departemen Pendidikan Bahasa Jepang, Fakultas Pendidikan Bahasa dan Sastra, Universitas \\ Pendidikan Indonesia \\ sepp_16@icloud.com
}

\begin{abstract}
Abstrak
Penelitian yang diberi judul "Analisis Kesalahan Penulisan Gairaigo pada Mahasiswa TK.I s.d TK.IV Pemokusan Pada Gairaigo Bahasa Inggris" bertujuan untuk mengetahui bagaimana faktor apa saja yang mempengaruhi dalam penulisan katakana yang terjadi pada mahasiswa. Dalam kosakata bahasa jepang ada yang disebut Gairaigo yaitu kata serapan yang digunakan dalam bahasa jepang. Kata serapan dalam bahasa jepang dewasa ini hampir 80 persen menggunakan bahasa Inggris. Penelitian terdahulu yang dilakukan menunjukan mahasiwa asih mengalami kesulitan dalam menulis gairaigo dalam huruf katakana. Maka faktor - faktor yang dianggap mempengaruhi mahasiswa dalam penulisan katakana adalah: (1) Tingkat di jurusan , (2) Level JLPT, (3) Apakah kata gairaigo tersebut familiar (4) Apakah ada ciri khas pelafalan, (5) Panjang pendeknya suatu kata. Dari hasil analisis tidak pengaruh antara lamanya belajar dan kemampuan bahasa jepang dengan menulis kata gairaigo. Mahasiswa kesulitan pada kata yang kurang familiar dan terdapat bunyi panjang atau chouon pada kosakata gairaigo. Dengan demikian sering melihat atau menggunakan kosakata itu dan apakah ada kekhasan pelafalan pada sebuah kata gairaigo memiliki pengaruh yang kuat.
\end{abstract}

Kata Kunci :Katakana, Gairaigo, Kesalahan penulisan

1. Dr. Herniwati, M.Hum. Penulis Penanggung Jawab 1

2. Dra. Renariah, M.Hum. Penulis Penanggung Jawab 2 


\title{
AN ANALYSIS ON FOGUSING KATAKANA ENGLISH LOANWOARDS WRITING ERRORS OF JAPANESE STUDENT IN INDONESIA UNIUERSITY OF EDUCATION
}

\author{
Septian Eka Pratama, Herniwati', Renariah² \\ Departemen Pendidikan Bahasa Jepang, Fakultas Pendidikan Bahasa dan Sastra, Universitas \\ Pendidikan Indonesia \\ sepp_16@icloud.com
}

\begin{abstract}
This research "An Analysis on Focusing Katakana English Loanwords Writing Errors of Japanese Student in Indonesia University of Education" has purpose to find many factors in loanword writing error. Gairaigo means loanwords in Japanese language are almost 80 percent from English. Many scholars pointed about Katakana Loanword writing rules. Many facts the Japanese loanwords are difficult for beginner Japanese foreigner learner. To get know why writing katakana words is hard. Ou said that he found that many Chinese native Japanese learners have many difficulties about Japanese Loanwords. The loanwords from American or Europe languages seem hard to recognize by Chinese Japanese learners even French Japanese learners. There are some reasons, but one of them is the differences of pronunciation from the origin words I tried to find one of numerous factors about that. Many factor related on this research such as JLPT, grade in college, characteristic of its loanwords, familiar and nonfamiliar words etc. One of the factors was found is about the characteristic about the Japanese loanword itself. The other is japanese system long vowel -toned in unfamiliar word by students.
\end{abstract}

Keyword : Effectiveness, Strategy Quick On The Draw, Vocabulary 


\section{PENDAHULUAN}

Dalam kosakata bahasa jepang ada yang disebut Gairaigo yaitu kata serapan yang digunakan dalam bahasa jepang. Kata serapan dalam bahasa jepang dewasa ini hampir 80 persen menggunakan bahasa Inggris. Pada tingkat dasar pembelajaran bahasa jepang huruf hiragana dan huruf katakana diajarkan secara intensif sebelum memulai pembelajaran lebih lanjutnya. Di Jurusan Pendidikan Bahasa Jepang UPI diadakan Orientasi Kana, yaitu mahasiswa diajarkan secara intensif untuk membaca, menulis dan menghafal huruf kana yaitu Hiragana dan Katakana.

Menurut Sawada ( 1993) dalam penelitian『日本語教育のための基本外来語につい $\tau 』$, Permasalahan yang sering terjadi dalam pembelajaran kosakata bahasa Jepang adalah pengadopsian bahasa Jepang yang sering dilakukan. Lanjutnya, Kesulitan yang ditemuinya pertama - tama adalah prononsiasi atau pengucapan, selanjutnya adalah asal usul makna, dan yang ketiga adalah cara penulisan.

Dari hasil semi penelitian yang menunjukan tidak ada satu orang pun yang bisa menjawab seluruh dengan benar maka saya menganggap penulisan katakana dianggap sulit. Untuk mengetahui bagaimana cara menulis katakana dengan benar maka perlu diketahui, faktor apa saja yang mempengaruhi dalam penulisan katakana yang terjadi pada mahasiswa.Dari hasil semi penelitian yang menunjukan tidak ada satu orang pun yang bisa menjawab seluruh dengan benar maka saya menganggap penulisan katakana dianggap sulit. Untuk menyelesaikan permasalahan ini perlunya penelitian yang sesuai kaidah agar bisa menganalisis kesalahan yang terjadi pada penulisan katakana dalam gairaigo. Masalah yang diteliti adalah (1) Hal yang mempengaruhi mahasiswa hingga mengalami kesalahan dalam menuliskan Gairaigo bahasa Inggris, (2) Jenis kesalahan yang dilakukan mahasiswa dalam menuliskan Gairaigo bahasa Inggris, (3) Upaya yang bisa mengatasi masalah mengenai kesalahan mahasiswa tersebut.

Hal ini bertujuan agar bermanfaat dalam dunia pengajaran dan pembelajaran bahasa Jepang tahap dasar, khususnya dalam menuliskan kata gairaigo dengan huruf katakana, baik sebagai bahan evaluasi pembelajaran maupun materi khusus untuk pengenalan katakana di tahap awal.

\section{METODE PENELITIAN}

Penelitian ini bertujuan untuk mengetahui jenis kesalahan yang dilakukan oleh mahasiswa dalam menuliskan kata gairaigo yang berasal dari bahasa inggris dengan huruf katakana. Dengan kata lain ini adalah salah satu cara untuk memberikan solusi terhadap kesalahan mahasiswa dalam hal penulisan kata gairaigo. Karena analisis kesalahan mahasiswa merupakan suatu garapan penelitian kependidikan, maka dapat disimpulkan penelitian ini termasuk penelitian kependidikan.

Sementara itu, objek penelitian bidang kependidikan biasanya menyangkut penyelenggaraan pendidikan atau pengajaran pada suatu lembaga, yang secara garis besarnya dapat dibagi menjadi tiga macam, yaitu : (1) program pengajaran, (2) proses pengajaran, dan (3) hasil belajar (Sutedi,2011: hlm. 27). Objek kajian dari penelitian ini adalah hasil pengajaran berupa kesalahan mahasiswa.

Sampel yang diambil penelitian adalah 40 mahasiswa yang terdiri sampel random dari Mahasiswa tingkat 1 sampai dengan tingkat 4 Jurusan Pendidikan Bahasa Jepang Universitas Pendidikan Indonesia Tahun ajaran 2013/2014

Untuk menganalisa kesalahan yang akan terjadi pada penulisan katakana pada gairaigo, dirumuskan pemilihan kata- kata yang relevan untuk dijadikan tes sebanyak 32 soal dengan jenis angket terbuka. Pelajar diminta untuk menuliskan huruf katakana yang berasal dari kata serapan

1. Dr. Herniwati, M.Hum. Penulis Penanggung Jawab 1

2. Dra. Renariah, M.Hum. Penulis Penanggung Jawab 2 
bahasa inggris yang dipakai dalam bahasa Jepang. Kata - kata tersebut Dalam rumusan masalah yang dijelaskan sebelumnya, ada faktor pelajar dan faktor kata. Faktor pelajar adalah termasuk aktor - faktor yang dianggap mempengaruhi mahasiswa dalam penulisan katakana adalah: (1) Tingkat di jurusan , (2) Level JLPT. Lalu faktor kata adalah (3) Apakah kata gairaigo tersebut familiar (4) Apakah ada ciri khas pelafalan, (5) Panjang pendeknya suatu kata.

Tes dilakukan dengan menggunakan one shoot mode, yaitu melaksnakan tes dengan serempak dalam satu waktu. Data yang diambil adalah data yang berupa kesalahan, kemudian diolah dan dianalisis sesuai dengan prosedur penelitian analisis kesalahan. Adapun prosedur penelitian dan langkah analisa data yang digunakan meliputi :

1. Memeriksa jawaban yang benar dan yang salah pada seluruh lembar jawaban.

2. Mengambil data yang berupa kesalahan dari hasil tersebut

3. Membuat table frekuensi dan persentase dari kesalahan-kesalahan tersebut

4. Analisa Classification Tree, yaitu sebuah model analisa yang berdasarkan diagram klasifikasi yang berbentuk seperti pohon yang bercabang- cabang untuk mengidentifikasi kelompok. Pada penelitian ini variabel - variabel yang digunakan adalah : (1) Tingkat di jurusan , (2) Level JLPT, (3) Apakah kata gairaigo tersebut familiar (4) Apakah ada ciri khas pelafalan, (5) Panjang pendeknya suatu kata.

5. Setelah didapatkan data yang berupa kesalahan - kesalahan pada penulisan katakana tersebut, dianalisis untuk menjawab seluruh masalah penelitian. Adapun langkah-langkah analisis data yang dilakukan adalah:

- Menyusun tabel frekuensi dan persentase sesuai rangking kesalahan yang dipaparkan pada tabel dan dijelaskan secara deskriptif.

- Menarik kesimpulan kesalahan-kesalahan apa saja yang muncul dalam penulisan huruf katakana.

- Menguraikan prediksi penyebab yang terjadi atas kesalahan dan hasil dari uji penelitian ini.

- Memberikan pembahasan secara teoritis pada setiap kesalahan sesuai dengan letak kesalahan dan prediksi faktor penyebabnya, sehingga dapat menemukan upaya apa yang didapat dilakukan untuk mengatasi permasalahan dalam penulisan katakana.

6. Menarik kesimpulan dan saran sesuai dengan hasil analisa data

\section{HASIL DAN PEMBAHASAN}

Dari semua responden yang terdiri 40 mahasiswa didapat 1280 jawaban yang beraneka ragam tingkat kesalahannya. Setelah diperiksa semua jawaban yang benar dan salah, Persentase jawaban benar adalah $45.2 \%$. Artinya kurang dari setengah responden yang menjawab dengan benar. Dari tingkat satu sampai empat tidak bisa dikatakan hanya tingkat tertentu yang bisa menjawab cenderung benar dan salah. Hal ini bisa dikatakan bahwa penulisan Katakana memang masih dirasa sulit bagi mahasiswa pembelajar di Indonesia, walaupun itu latar belakang dari responden adalah pendidikan di perguruan tinggi. Dari tiap-tiap kata yang dijawab oleh responden bisa diketahui jugaperbedaan tingkat persentase jawaban. Dari 32 kata katakana yang ada pada soal yang mempunyai tingkat jawaban yang benar paling tinggi adalah kata サイ ズ. $95 \%$ dari responden menjawab benar. Berdasarkan faktor-faktor yang dibuat pada tiap kata pada penelitian ini kata ini termasuk pendek dan masuk kategori kata pada kata yang familiar atau 既習 (Kishuu), dan tidak ada ciri khas pelafalan atau dalam istilah bahasa Jepang nya 直 音(Chokuon). Selanjutnya soal yang mempunyai tingkat jawaban yang benar paling tinggi adalah kata ブランド. Persentase jawaban benarnya adalah $82.5 \%$. Selanjutnya, yang paling kecil adalah kata ルーズ hanya 1 orang artinya hanya $3 \%$ yang menjawab kata ini dengan benar. Kata ini termasuk kata pendek yang kurang familiar atau 未習(mishuu) mempunyai pelafalan nada panjang pada tengah kata. Selanjutnya adalah kata コマーシャル, kata ini 
termasuk kata yang kurang familiar dan terdapat bunyi pelafalan panjang di tengah kata, selanjuntnya kata ベンチャー, kata termasuk kata golongan panjang yang kurang familiar terdapat bunyi pelafalan panjang pada bagian akhir kata, dan yang terakhir paling kecil persentase jawaban benarnya adalah kata コミュニティー、Kata ini kata golongan panjang yang kurang familiar dan terdapat bunyi pelafalan panjang pada akhir kata. Ketiga kata tersebut hanya mempunyai persentase benarnya adalah $10 \%$ dari 40 responden.

Dengan Analisis Classification Tree, yang dianggap susah oleh para mahasiswa atau pelajar bahasa Jepang dalam penulisan kata serapan asing Jepang denan huruf katakana adalah kata yang kurang begitu familiar dan memiliki pelafalan bunyi panjang pada tengah atau akhir kata. Kata-kata terebut memiliki persentase jawaban benar yang rendah yaitu diangka $31.0 \%$. Lalu tidak ada pengaruh sama sekali antara faktor dari segi lamanya mahasiswa belajar ataupun kemampuan bahasa Jepang dalam tingkatan JLPT. Secara jelasnya, Seorang mahasiswa yang sudah belajar selama 4 tahun dengan mahasiswa yang baru belajar 1 tahun, tidak ada kaitan dengan apakah ia bisa menuliskan katakana dengan benar.

jenis -jenis kesalahan yang dilakukan mahasiswa berdasarkan faktor-faktor yang lebih detail penulis akan mengelompokkan jenis-jenis kesalahan pada tiap kata. Manakah kesalahan yang paling sering terjadi pada tiap kata. Untuk mempermudah dalam proses analisis dibagi 4 kelompok. Pada penelitian ini diperoleh 1280 buah jawaban dari 40 koresponden yang terdiri mahasiswa. Dari data tersebut diperoleh data yang berupa kesalahan yang terjadi 683 jawaban.

Berikut dibawah ini adalah 4 kelompok:

Tipe 1 : Kesalahan bentuk tulisan atau disebut Hyouki miss 表記ミス

Contoh: ヘンドブック pada Q23 (ハンドブック)

Jenis kesalahan ini merupakan kesalahan pada penggunaan huruf yang keliru pada penulisan katakan

Tipe 2 : Kesalahan bunyi gesek dan bunyi letus atau disebut Seidaku miss 清濁のミス Contoh: キャップ pada (Q22 ギャップ)

Jenis kesalahan ini merupakan kesalahan pada penggunaan dakuon atau handakuon yang keliru pada penulisan katakana

Tipe 3 : Kesalahan mora/ketukan atau disebut Haku no miss 拍のミス

Contoh:アプ pada (Q20 アップ)、ボランティアー pada

(Q6 ボランティア)

Jenis kesalahan ini merupakan kesalahan pada ketukan atau mora pada kata dalam penulisan katakana. Seperti nada panjang yang perlu ditulis tidak ditulis atau sebaliknya

Tipe 0 : Kesalahan 2 macam atau lebih

Contoh:コッメルシャール pada (Q8 コマーシャル)

Jenis kesalahan ini terjadi karena terdapat dua atau lebih kesalahan yang terjadi pada penulisan katakana. Seperti pada contoh diatas terdapat ada kesalahan bentuk penulisan dan kesalahan ketukan pada kata.

Pertama, hasil persentase pada jenis-jenis kesalahan yang paling banyak terjadi adalah kesalahan Tipe 0, yaitu kesalahan yang disebabkan oleh 2 jenis kesalahan. Sebanyak $46.41 \%$ Tipe 0 ini terjadi pada hasil tabel 3 tersebut. Dengan demikian mahasiswa ketika menuliskan kata gairaigo hampir dari setengahnya melakukan dua kesalahan. Lalu pengaruh panjangnya suatu kata bisa mempengaruhi mahasiswa dalam menuliskan kata gairaigo secara benar. Seperti

1. Dr. Herniwati, M.Hum. Penulis Penanggung Jawab 1

2. Dra. Renariah, M.Hum. Penulis Penanggung Jawab 2 
kata- kata「コマーシャル」、「ベンチャー」、「プライバシー」「コミュニティー」 「デモンストレーション」 termasuk kelompok kata panjang terjadi kesalahan dilakukan oleh 20 mahasiswa.

Kedua, kesalahan yang banyak terjadi selain tipe 0 adalah Tipe 3 yaitu kesalahan mora atau ketukan artinya responden sangat mudah melakukan kesalahan pada bagian ketukan atau mora. Sebanyak $25.92 \%$ melakukan kesalahan ini. Ada beberapa hal yang menjadi penyebab kesalahan ini terjadi yang disimpulkan penulis, yaitu: Kurangnya pemahaman mahasiswa pada aturan penulisan gairaigo, pembelajaran katakana yang sangat singkat sehingga hanya belajar huruf gairaigo secara alami mengikuti materi perkuliahan, dan penyebab lainnya karena bahasa ibu yang tidak ada penulisan khusus pada bunyi panjang suatu kata.

Ketiga, pada keseluruhan tipe kesalahan, yang paling sedikit mengalami kesalahan adalah tipe seidaku miss atau kesalahan pada bunyi gesek dan bunyi letus. Sekitar $8.35 \%$ dari responden melakukan kesalahan pada tipe ini.

\section{KESIMPULAN}

Hal-hal yang disimpulkan sesuai dengan rumusan masalah adalah sebagai berikut :

1. Pada tahap ini, setelah melakukan penelitian pada 40 mahasiswa dan diketahui rata - rata jawaban benar dari seluruh objek penelitian sebanyak 45.2\% . Dari hal ini bisa diketahui bahwa kurang dari setengah populasi sampel yang dapat menjawab atau mengisi dengan benar. Dengan melakukan analisis classification tree diketahui faktor - faktor yang mempengaruhi mahasiswa mengalami kesalahan dalam menuliskan Gairaigo bahasa Inggris. Jika dilihat dari grafik 4.1 hasilnya adalah pertama yang paling kuat mempengaruhi adalah apakah gairaigo itu familiar ( 既習) atau tidak (未習)、perbandingan persentase jawaban benar adalah $50.5 \%$ untuk kata familiar dan $39.7 \%$ untuk kata yang tidak atau kurang familiar. Kedua adalah panjang atau tidaknya kata tersebut. Persentasenya adalah 54.3\% untuk kata yang tergolong pendek dan $46.9 \%$ untuk kata yang tergolong panjang. Mengenai faktor dari sisi mahasiswa yang terdiri dari lamanya belajar bahasa jepang dan kemampuan JLPT tidak muncul pada grafik pohon hasil analisa. Hal ini dapat dikatakan tidak ada hubungan atau keterkaitan lama belajar dan kemampuan bahasa Jepang dari nilai JLPT dengan kemampuan menuliskan gairaigo bahasa Inggris.

2. Hasil analisis yang sama yang dianggap susah oleh para mahasiswa atau pelajar bahasa Jepang dalam penulisan kata serapan asing Jepang dengan huruf katakana adalah kata yang kurang begitu familiar dan memiliki pelafalan bunyi panjang pada tengah atau akhir kata.

Berdasarkan analisis dari kesalahan yang terjadi diberi beberapa teori mengenai tipe-tipe kesalahan, hal ini untuk memudahkan membuat strategi untuk membantu pembelajaran Katakana ini. Tipe - tipenya adalah sebagai berikut :

A. Tipe 1 : Kesalahan bentuk tulisan atau disebut Hyouki miss 表記ミス

Seperti pada kata ヘンドブック pada Q23 (ハンドブック). Jenis kesalahan ini merupakan kesalahan pada penggunaan huruf yang keliru pada penulisan katakana

B. Tipe 2 : Kesalahan bunyi gesek dan bunyi letus atau disebut Seidaku miss 清濁のミス 
Seperti pada kata キャップ pada $(\mathrm{Q} 22$ ギャップ $)$, jenis kesalahan ini merupakan kesalahan pada penggunaan dakuon atau handakuon yang keliru pada penulisan katakana

C. Tipe 3 : Kesalahan mora/ketukan atau disebut Haku no miss 拍のミス

Seperti pada kata アプ pada (Q20 アップ)、ボランティアー pada soal (Q6 ボランティア),jenis kesalahan ini merupakan kesalahan pada ketukan atau mora pada kata dalam penulisan katakana. Seperti nada panjang yang perlu ditulis tidak ditulis atau sebaliknya

D. Tipe 0 : Kesalahan 2 macam atau lebih

Seperti pada kata コッメルシャール pada (Q8 コマーシャル), jenis kesalahan ini terjadi karena terdapat dua atau lebih kesalahan yang terjadi pada penulisan katakana. Seperti pada contoh diatas terdapat ada kesalahan bentuk penulisan dan kesalahan ketukan pada kata.

3. Setelah mengetahui pengaruh yang mempengaruhi mahasiswa mengalami kesalahan dalam menuliskan gairaigo bahasa Inggris dan mengetahui jenis- jenis kesalahan yang dilakukan. Maka sebagai suatu rujukan, berdasar penelitian yang telah dilaksanakan mahasiswa merasa kesulitan pada gairaigo yang kurang begitu dia lihat dalam bentuk katakana. Pengenalan kosakata gairaigo dalam bentuk bahasa Jepang yang berarti dalam sistem bahasa Jepang membantu mahasiswa dalam menuliskan huruf gairaigo.

\section{REFERENSI}

Dalton, Frank E. 2008. Japan's built in Lexicon of English. Multilingual matters. Clevedon, United Kingdom

Dahidi, Amad, dkk. Edisi Agustus. Analisis Kesalahan. Media Komunikasi. ASPBJI Korwil Jabar. Diterbitkan.

Hamada, M. (2006) Daigakusei to ryugaku no ronbun waaku bukku. Tokyo : Kuroshio Shuppan

Hayakawa, S. Tamaoka, Kim (2011). Onsei kara shoji e no tenkan to sono choukai e eikyoo. No. 87

Japan Foundation ( 1995) Nihongo kana Nyumon. Tokyo : Bonjinsha

Jinnai, M. (2008). Nihongo gakushuusha no katakana go ishiki to katakana go kyouiku. Gengo to bunka 11,47-60

Mochizuki, M.(2012). Kihongoka o kooryoshita katakana gairaigono gakushuusha to kyouzai kaihatsu: sono furi kaeri to arata na kaihatsu ni mukete. Gaikokugo gakubu kiyoo 6, 116

Sawada, T. (1993) Nihongo kyouiku no tame no kihon gairaigo ni tsuite 225-239.Nara Kyouiku daigaku Journal. Ninbun Shakai. No.42(1)

1. Dr. Herniwati, M.Hum. Penulis Penanggung Jawab 1

2. Dra. Renariah, M.Hum. Penulis Penanggung Jawab 2 
JAPANEDU, Vol. 1, No. 1, Juni 2016

\author{
インドネシア教育大学 1 回生から 4 回生の日本語学習者を対象とした \\ 外来語の誤表記分析 \\ 一英語由来の外来語を中心として一 \\ Septian Eka Pratama, Herniwati', Renariah² \\ Departemen Pendidikan Bahasa Jepang, Fakultas Pendidikan Bahasa dan Sastra, Universitas \\ Pendidikan Indonesia \\ sepp_16@icloud.com
}

\begin{abstract}
要旨
インドネシア語にも英語由来の外来語は多く、また日本語学習者の多くは、すでに英語を習得 しているが、その英語由来の外来語であっても、難しいと感じることが多い。2012年に行った 調査では、外来語を表記する際に文字を混同し、濁音のミスなども多くあった。そこで、本研 究では、インドネシア教育大学 1 回生から 4 回生の日本語学習者がどのようにすれば外来語を 正しく表記できるようになるかを知る 1 つの手がかりとして、インドネシア教育大学 1 回生か ら 4 回生の日本語学習者が外来語をどのように書くかを調査した。日本語能力と日本語学習期 間の要因としては有意になかった。外来語の表記で最も学習者にとって易しいのは、既習の語 の中短い語であることが分かった。ほかの語と比べて、正確に表記することが難しくなかった のではないであろうか。その他は、最も難しいのは、未習語長音含む語であることが分かった。 つまり、出題される言葉の日本語の語として触れた経験のある外来語とその言葉の特徴によっ て影響が強い。
\end{abstract}

キーワード : カタカナ、外来語、誤表記

1. はじめに 
近年インドネシアでは、日本語学習者が増加している。彼らの多くは、外来語には苦手意識 を持っている。インドネシア語にも英語由来の外来語は多く、また日本語学習者の多くは、す でに英語を習得しているが、その英語由来の外来語であっても、難しいと感じることが多い。 筆者自身も外来語を書くときに辞書を調べなければ書けない外来語も少なくない。そのような 自分の経験に基づいて、2012年12月上旬に同級生や下級生10名を対象に小調査を行った。その 際には教科書で学習した外来語（みんなの日本語 I・II）を項目作成の参考にしたが，全て正 確に外来語を書けた学生はいなかった。その時に外来語は難しいと思った。では，なぜ外来語 はそれほど難しいのか。問題になる点は何であろうか。これらを知るために、日本語学習者は 外来語をどう間違っているのか調査する必要があると考えた。外来語が難しい大きな理由の 1 つは、外国語の音を転記する時に実際の語と異なってしまうためであると考えられる。もう 1 つの理由はカタカナ語の表記が難しいということである。2012年に行った調査では、外来語を 表記する際に文字を混同し、濁音のミスなども多くあった。そこで、本研究では、インドネシ ア教育大学 1 回生から 4 回生の日本語学習者がどのようにすれば外来語を正しく表記できるよ うになるかを知る 1 つの手がかりとして、インドネシア教育大学 1 回生から 4 回生の日本語学 習者が外来語をどのように書くかを調査する。外来語に現れる誤表記を分析し、日本語教育一 応用することを目的とする。

実際、日本語学習者が正しく外来語を書き表すことは困難であることを示した研究がある。 早川・玉岡・金(2011) では、英語からの借用語である外来語を中心に、音声から書字への転換 とその聴解への影響を明らかにするために、英語から日本語に借用された外来語を韓国人日本 語学習者がどれくらい正確に書き取ることができるか、調査している。その結果、英語由来の 外来語で、既に英語としては知っている語であっても、外来語に書き表すのは難しいことがわ かった。以上の研究結果から、インドネシア教育大学 1 回生から 4 回生の日本語学習者にとっ ても、英語の語彙またはインドネシア語に借用されている英語を多く知っていても、日本語の 外来語を正しく表記することは困難であることが予想される。ただし、早川・玉岡・金 (2011) では、どのような要因が外来語の表記の困難さに影響するのか、明らかにされているわけでは ない。また、早川・玉岡・金(2011)の調査に使用した語は、全て日本語の外来語としてはなじ みがない語であった。つまり、日本語としてこれらの外来語を知っていれば正しく表記できる のか、ということは分からない。さらに、音声で提示された外来語を表記するということは、 外来語を知っているかというより、音声をルールに従ってカタカナで表記できるかを測ってい るとも考えられ、作文などで外来語を表記する必要があるときに正しく表記できるのかという ことと同じではないと考えられる。

そこで、本研究では日本語の外来語を正しく表記することにどのような要因が影響している のか、調查対象者の (1) 日本語能力、（2）日本語学習期間、出題される外来語の (3)未習・既習、 (4) 語に含まれる特殊音の有無、（5)語の長さという5つの要因を設定し、明らかにする。また、

1. Dr. Herniwati, M.Hum. Penulis Penanggung Jawab 1

2. Dra. Renariah, M.Hum. Penulis Penanggung Jawab 2 
JAPANEDU, Vol. 1, No. 1, Juni 2016

外来語の誤表記に見られる特徵は何か、明らかにする。

\section{2. 調查の対象と範囲}

本研究における調査対象者は、同じ大学の同じカリキュラムで日本語を学習しているが、彼 らが使用した初級レベルの日本語の主教材は、『みんなの日本語』であった。また、すべての調 査対象者は『みんなの日本語』を学習寸るのに先立って、ひらがな・カタカナの文字教育も受 けている。なお、本研究の調査対象者は全て『みんなの日本語』を終えている初級後半以上の 学習者である。

調査は、英語で表記した語をカタカナ表記する形式の調査紙で行った。調査紙で問題とした 項目は、全32項目である。出題した語は、(1)未習・既習、(2)語に含まれる特殊音の有無、(3) 語の長さを考慮して選択した。（1）未習・既習の判断は、『みんなの日本語の初級 I. II』に含ま れている語であれば既習、それ以外の外来語で、他の日本語教材にある語は未習とした。どの ような外来語が『みんなの日本語』に含まれているか、他の日本語教材に含まれているかは、 望月（2012）を参照した。（2）語に含まれる特殊音の有無は、促音が含まれる語・長音が語中に含 まれる語・語尾に長音が含まれる語・促音も長音も含まない語の 4 種からなる。（3）語の長さは 拍を基準として選択した。一つの仮説として短い言葉と長い言葉を比較する必要があったので、 長い言葉と短い語を分けた。したがって、基準を決めたうえで、3 拍以下の言葉と 4 拍以上言 葉の代表にして入れた。本当に長いのと短いグループには差があるのか。 本研究で用いた語の拍の平均を $t$ 検定により比較したところ、既習語の長い語（平均 5.25 拍、 $\mathrm{SD}=0.46$ 拍）は短い語（平均 3.00 拍、 $\mathrm{SD}=0.54$ 拍）より有意に長かった $[t(7)=9.000, p<.001]$ 。 また、未習語の長い語（平均 5.63 拍、 $\mathrm{SD}=1.60$ 拍）も短い語（平均 3.38 拍、 $\mathrm{SD}=0.74$ 拍）より 有意に長かった $[t(7)=3.631, p<.01]$ 。以上のような条件の語を各 2 語選択し、 $2 \times 2$ （未習・ 既習） $\times 4 （$ 促音が含まれる語・長音が語中に含まれる語・語尾に長音が含まれる語・促音も 長音も含まない語） $\times 2$ (長い語 $\times$ 短い語） $=32$ 語という構成にした。

\section{3. 分析の結果}

本研究ではClassification Tree を用い、(1) 日本語学習期間、(2) 日本語能力試験取得級の 2 つの被験者要因と外来語の（3）未習・既習、(4) 語に含まれる特殊音の有無、(5)語の長さの 5 つの説明変数で、外来語の表記の正誤を予測した 
Pratama, Herniwati, Renariah, An Analysis on Focusing Katakana

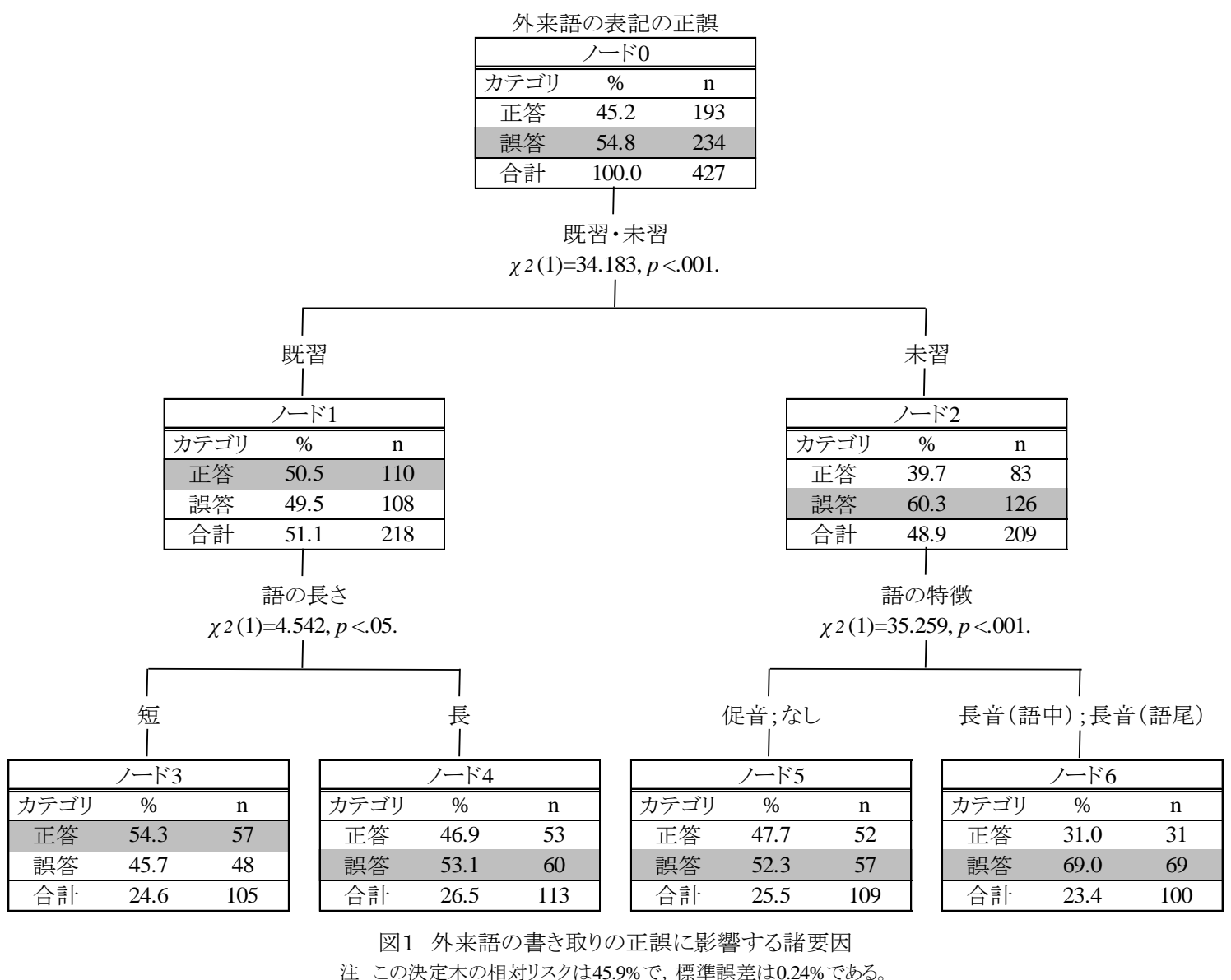

図 1 によると、外来語表記の正誤に最も強く影響を及ぼすのは、その外来語が未習であるか既 習であるか、ということであった $\left[\chi^{2}(1)=34.183 ， p<.001.\right]$ 。既習の語であれば、 $50.5 \% の$ 正答 率で正しく表記することができるが、未習の語であれば、39.7\%の正答率で正しく表記すること ができる。樹形図によると、両者の正答率には有意な差が見られる。語の既習／未習によって 次に外来語表記の正誤に影響する要因が異なる。以下、語の既習/未習に分けて結果をまとめ る。既習の語の場合、次に外来語の表記の正誤に影響を及ぼすのは、語の長さであった。短い 語の場合 $(54.3 \%)$ 、長い語の場合 $(46.9 \%)$ より有意に正しく表記できることが分かった $[x$ ${ }^{2}(1)=4.542 ， p<.05$. ]。一方、未習の語の場合、次に外来語の表記の正誤に影響を及ぼすのは、 語の特徵であった。促音が含まれる語または直音のみで構成される語の場合 $(47.7 \%)$ 、語中・語 尾にかかわらず長音を含む語の場合 (31.0\%) より有意に正しく表記できることが分かった $[x$ $\left.{ }^{2}(1)=35.259, \quad p<.001.\right]$ 。また、外来語の表記の正誤に影響する要因として設定した被験者要因 は、日本語学習期間、日本語能力試験取得級共に樹形図に描かれなかったことから、外来語の 表記の正誤には全く影響を及ぼさないことが分かった。

インドネシア教育大学 1 回生から 4 回生の日本語学習者の外来語の誤表記の原因をさらに詳 細に明らかにするために、各語の誤表記のタイプを分類し、どのような誤表記が多いか、それ はなぜかを考察する。

1. Dr. Herniwati, M.Hum. Penulis Penanggung Jawab 1

2. Dra. Renariah, M.Hum. Penulis Penanggung Jawab 2 
本研究では、以下のように, 外来語の誤表記のタイプを正解も含め, 便宜上 4 種類に分類し た。なお、本研究の調查対象者 40 名の総回答数は 1,280 回答で、そのうち誤答と認められたの は、全部で 683 回答であった。

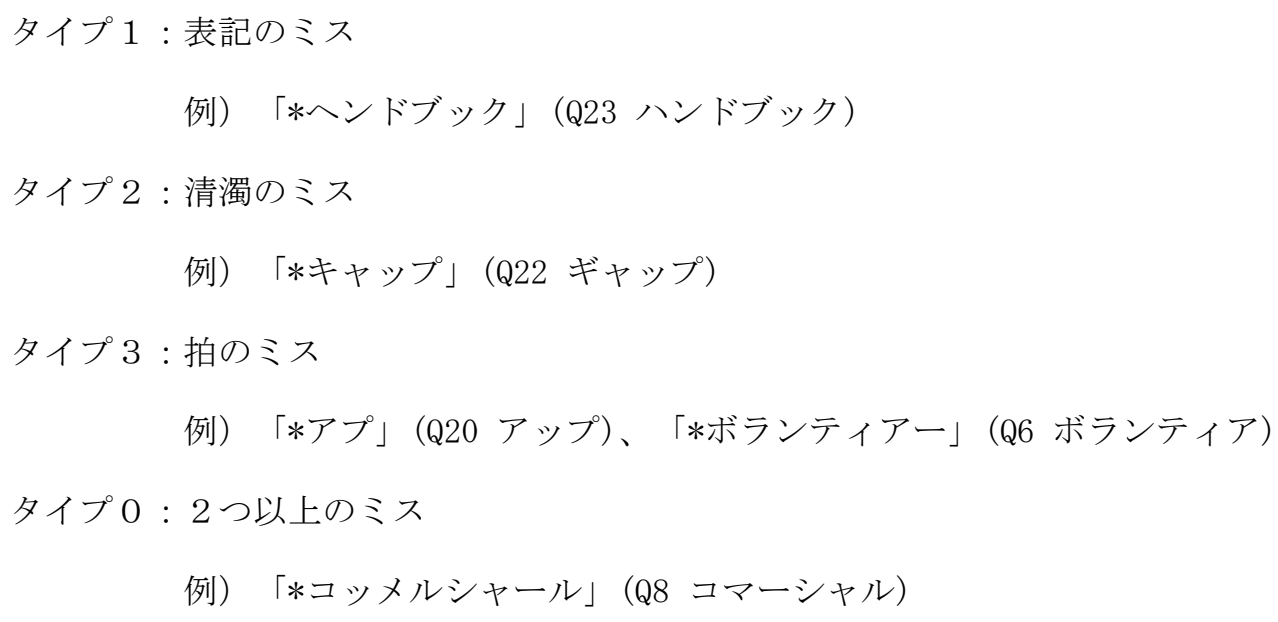

\section{4.おわりに}

\section{まとめ}

以上、本稿で述べてきたことをまとめると以下のようになる。インドネシア教育大学 1 回生 から 4 回生の日本語学習者を対象とした外来語の誤表記分析をした上で、日本語能力と日本語 学習期間の要因としては有意になかった。外来語の表記で最も学習者にとって易しいのは、既 習の語の中短い語であることが分かった。ほかの語と比べて、正確に表記することが難しくな かったのではないであろうか。その他は、最も難しいのは、未習語長音含む語であることが分 かった。つまり、出題される言葉の日本語の語として触れた経験のある外来語とその言葉の特 徵によって影響が強い。

既に述べたように表 2 の誤表記タイプとその割合の結果をみると、外来語の誤表記のタイプを 正解も含め、4 種類に分けた。以下のようになる

タイプ1：表記のミス

例）「*ヘンドブック」（Q23 ハンドブック）

タイプ $2:$ 清濁のミス

例）「*キャップ」（Q22 ギャップ） 
タイプ $3:$ 拍のミス

例）「*アプ」(Q20 アップ)、「*ボランティアー」(Q6 ボランティア $)$

タイプ0：2つ以上のミス

例）「*コッメルシャール」（Q8 コマーシャル）

タイプ 0 を除く, タイプ 3 (拍のミス)が最も多く、全体の誤表記の $25.92 \%$ 占めていることが 分かった。

また、以上のように、インドネシア教育大学 1 回生から 4 回生の日本語学習者のためにカタカ ナ表記の仕方やルールをちやんとしたメソードで改めて教えて、外来語のそのままから書き換 えられることも必要だが、日本語の語としてカタカナ語を触れるような方法は学習者にとって 易しいのではないかと思う。

\section{今後の課題}

本研究で明らかにした誤表記分析した上の外来語の誤表記に見られる特徴はもっと細かく分析 するという問題は今後の課題に残されたである。後は教育面に外来語を教えるための工夫やス トラテジーなどを研究する必要があるのではないかと思う。特に日本語能力と日本語の勉強期 間よりで語の特徵のうち拍や表記ミスなどをもっと指摘すればいいのである。誤表記のタイプ をもっと細かくする必要があるである。

\section{5. 引用・参考文献}

(英語)

Dalton 、Frank. E. 2008. Japan's built in Lexicon of English. Multilingual matters. Clevedon, UK

Sudjianto dan Ahmad Dahidi. 2007. Pengantar linguistik Bahasa jepang. Kesaint blanc. (日本語）

王伸子

1. Dr. Herniwati, M.Hum. Penulis Penanggung Jawab 1

2. Dra. Renariah, M.Hum. Penulis Penanggung Jawab 2 
JAPANEDU, Vol. 1, No. 1, Juni 2016

川口義一・横溝紳一（2003）『日本語教育ガイドブック』ひつじ書房

国立国語研究所（2005）『外来語に関する意識』国立国語研究所

国際交流基金（1995）『日本語かな入門』凡人社

澤田田津子 (1993)「日本語教育のための基本外来語について」『奈良教育大学紀要（人文社会)』 $42(1) 、 225-239$.

陣内正敬（2009）「日本語学習者のカタカナ語意識とカタカナ語教育」『言語文化』11号、4759. 関西学院大学

浜田麻里・平尾得子・由井紀久子（2006）『大学生と留学生のための論文ワークブック』くろし お出版

早川杏子・玉岡賀津雅・金秀眞（2011）「音声から書字一の転換とその聴解へ影響」87号

望月通子（2012）『基本語化を考慮したカタカナ外来語の学習と教材開発』6 号

澤田田津子（1993）「日本語教育のための基本外来語について」『奈良教育大学紀要』 